\title{
Comparison of Natural Dyes from Telang Flower Extracts (Clitoria ternatea $L$ ) as a Substitute for Methylen Blue in Diff Quik Painting
}

\section{Perbandingan Pewarna Alami dari Ekstrak Bunga Telang (Clitoria ternatea L) sebagai Pengganti Methylen Blue pada Pengecatan Diff Quik}

\author{
Elsa Nurita $\mathrm{Azka}^{1)}$, Andita Ayu Mandasari ${ }^{2)}$, Setyo Dwi Santoso ${ }^{3)}$ \\ Program Diploma III Teknologi Laboratorium Medik. Universitas Maarif Hasyim Latif \\ \{elsanurita7@gmail.com $\}$
}

\begin{abstract}
Telang flower (Clitorea ternatea $L$ ) is a type of vine that grows wild in rice fields and has been widely used as food coloring. Telang flowers contain several active compounds, which is anthocyanin gives a blue color. This research was conducted with the aim of knowing the telang flower extract as a natural dye to substitute methylenen blue in diff quik painting. The analysis samples used were oral mucosal ephithelial cells which were taken by scraping the oral mucosa using cytobrush. Dried and mashed telang flower was then dissolved with distilled water (1:5) to make an extracts before the trial process of the samples. The results showed that the epithelial cells stained with methylene blue were better than telang flower extract. The immersion time of 15 minutes gave different colors to the cell nucleus and cytoplasm compared to 2 minutes and 5 minutes of immersion.
\end{abstract}

Keywords - Telang flower; Natural dyes; Citology

\begin{abstract}
Abstrak. Bunga telang (Clitorea ternatea L) merupakan jenis tumbuhan merambat yang tumbuh liar di area persawahan dan telah banyak digunakan sebagai pewarna makanan. Bunga telang memiliki beberapa kandungan senyawa aktif salah satunya adalah antosianin yang memberi warna biru. Penelitian ini dilakukan dengan tujuan untuk mengetahui ekstrak bunga telang sebagai pewarna alami penganti methylen blue pada pengecatan diff quik. Sampel analisa yang digunakan adalah sel epitel mukosa mulut yang diambil dengan cara mengerok mukosa mulut menggunakan cytobrush. Bunga telang yang telah dikeringkan dan dihaluskan kemudian dilarutkan dengan akuades (1:5) untuk membuat ekstrak sebelum proses uji coba terhadap sampel uji. Dari hasil penelitian menunjukan bahwa sel epitel yang diwarnai dengan methylen blue lebih baik dibandingkan dengan pewarnaan ekstrak bunga telang, pada waktu perendaman 15 menit memberikan warna yang berbeda pada inti sel dan sitoplasma dibandingkan dengan perendaman selama 2 menit dan 5 menit.
\end{abstract}

Kata Kunci-Bunga telang; Pewarna alami; Sitologi

\section{Pendahuluan}

Bunga telang (Clitoria ternatea L) merupakan bunga yang berasal dari daerah Ternate, Maluku. Tumbuhan ini dapat hidup didaerah tropis seperti Asia. Penyebarannya telah sampai Amerika Selatan, Afrika, Brazil, Pasifik Utara, dan Amerika Utara. Bunga telang juga dikenal dengan nama Butterfly pea di Inggris dan Mazerion Hidi di Arab [7].

Bunga telang mengandung senyawa aktif yang memiliki potensi farmakologi. Potensi farmakologi adalah sebagai antibakteri, antioksidan, anti inflamasi dan analgesik, antiparasit dan antikanker. Selain itu senyawa yang terkandung dalam bunga telang antara lain adalah tanin, flobatanin, karbohidrat, saponin, triterpenol, flavonol glikosida, protein, alkaloid, antrakuinon dan antosianin [7].

Senyawa Antosianin merupakan pigmen dari golongan flavonoid yang mudah larut dalam air dan memberikan warna biru pada bunga telang [7]. Selain pigmen warna biru, antosianin juga mempunyai pigmen yang berwarna merah, ungu, biru, kuning dan tak berwarna Menurut [2], antosianin larut dalam pelarut polar adalah seperti metanol, aseton, klorofom dan air yang telah diasamkan dengan asam klorida atau asam [13].

Salah satu pengecatan sitologi adalah pengecatan diff quik yang merupakan modifikasi dari Romanowsky stain. Pengecatan ini digunakan untuk membedakan sel dalam preparat patologi. Keuntungan pengecatan ini adalah membutuhkan waktu yang relatif singkat dan mampu memberikan warna yang baik pada hapusan darah. Kandungan 
pewarnaan romanowsky adalah pewarnaan basa atau kationik seperti azure B atau methylen blue yang menghasikan warna biru. Pewarnaan asam atau anion seperti eosin Y menghasilkan warna merah [3] [6]. Larutan methylen blue yang memberikan warna biru pada inti sel dan larutan eosin yang memberikan warna merah pada sitoplasma [4].

Beberapa komponen yang terdapat pada pengecatan diff quik salah satunya methyelen blue. Methyelen blue adalah senyawa azo dan mempunyai turunan gugus benzena dengan sifat non-biodegrable yang bersifat toksik yang menyebabkan mutasi genetik, iritasi seluran pernafasan dan berpengaruh pada reproduksi [8] [15]. Menurut [11] efek yang terjadi dapat berupa sakit kepala, sesak nafas, dan mual pada perut. Pada penelitian sebelumnya yang dilakukan oleh [5], untuk ekstraksi bunga telang dapat digunakan pewarnaan untuk membedakan sel darah pada hewan.

Oleh karena itu, peneliti ingin melakukan suatu penelitian menggunakan bahan alami bunga telang (Clitoria ternatea $L$ ) sebagai pewarna alami sel mukosa mulut sebagai pengganti metylen blue.

\section{METODE}

Metode penelitian yang digunakan dalam penelitian ini adalah percobaan laboratorium yaitu suatu metode untuk mengetahui kemampuan ekstrak bunga telang sebagai pengganti metylen blue pada pengecatan diff quik.

\section{A. Pembuatan Ekstrak Bunga Telang}

langkah awal sampel bunga telang yang telah diperoleh dikeringkan menggunakan oven. Bunga telang yang telah dikeringkan diblander sampai menjadi serbuk. Setelah itu ditambahkan akuades steril dengan perbandingan 1:5, kemudian disaring dengan kertas saring whatman. Filtrat hasil saringan dari proses sebelumnya ditambahkan $1 \mathrm{ml} 1 \%$ alluminium chlorida anhidrat dan $1 \mathrm{ml}$ Fe chlorid Hexahidrat 1,2\% dicampur.

\section{B. Pembuatan Sediaan Sitologi}

Persiapan sampel sel epitel mukosa mulut. Sebelum melakukan pengambilan sampel sel epitel mukosa mulut sebaiknya diminta untuk berkumur terlebih dahulu, untuk menghilangkan sisa sisa makanan. Mukosa dicerok menggunakan cytobrush dengan sedikit penekanan dalam satu arah secara berulang-ulang. Hasil cerokan dioleskan ke kaca objek dan dikeringkan sebentar.

\section{Pewarnaan Sel Epitel menggunakan Diff Quik}

Pewarnaan diff quik 25 sediaan sebagai kontrol. Preparat yang telah kering difiksasi dengan methanol \pm 10 kali celupan. Kemudian ditiriskan lalu dicelupkan pada eosin sebanyak \pm 10 kali celupan. Pada methyelen blue sebanyak \pm 10 kali celupan. Setelah itu celupkan kedalam air sebanyak 5-7 kali hingga tidak ada cat sisa. Keringkan dan siap untuk dilakukan pengamatan dibawah mikroskop dengan pembesaran $400 \times$.

\section{Pewarnaan Sel Epitel Menggunakan Bunga Telang}

Preparat yang telah kering difiksasi dengan methanol sebanyak \pm 10 kali celupan. Kemudian ditiriskan lalu dicelupkan pada eosin sebanyak \pm 10 kali celupan. Rendam pada pewarna bunga telang selama 2 menit, 5 menit dan 15 menit. Setelah itu celupkan kedalam air sebanyak 5-7 kali hingga tidak ada cat sisa. Keringkan dan siap untuk dilakukan pengamatan dibawah mikroskop dengan pembesaran $400 \times$.

\section{Hasil Dan Pembahasan}

Uji pembuktian antosianin pada bunga telang (Clitoria ternatea $L$ ) hasil ditunjukan pada tabel 1. Larutan ekstrak bunga telang (Clitoria ternatea L.) yang telah dibuat sebagai eksperimen dan pewarnaan diff quick sebagai kontrol untuk dijadikan pewarnaan pada sampel sel mukosa mulut setelah itu dilakukan pengamatan secara makroskopis pada tabel 2 . 
Procedia of Engineering and Life Science Vol. 1. No. 2 Juni 2021

Seminar Nasional \& Call Paper Fakultas Sains dan Teknologi (SENASAINS 2nd)

Universitas Muhammadiyah Sidoarjo

\begin{tabular}{lccccc}
\hline No & Senyawa & Pereaksi & Reaksi positif & Hasil & Keterangan \\
\hline 1 & Antosianin & 7ml ekstra bunga ditambahkan & Larutan berubah & Terbentuk & Potitif \\
& & 2 tetes reagen $\mathrm{NaOH} 10 \%$ & warna menjadi & larutan & \\
& & menjadi coklat lalu tambahkan & merah. & berwarna merah & \\
& & & & \\
\hline
\end{tabular}

Tabel 2. Hasil Pengamatan Makroskopis

\begin{tabular}{|c|c|c|}
\hline No & Perlakuan & Hasil \\
\hline 1 & $\begin{array}{l}\text { Perendaman sel epitel dengan ekstrak } \\
\text { bunga telang selama } 2 \text { menit. }\end{array}$ & wama inti dan sitoplasma sel epitel berwama merah \\
\hline 2 & $\begin{array}{l}\text { Perendaman sel epitel dengan ekstrak } \\
\text { bunga telang selama } 5 \text { menit }\end{array}$ & $\begin{array}{l}\text { wama inti sel sedikit lebih gelap dengan sitoplasma } \\
\text { yang berwama sedikit keunguan. }\end{array}$ \\
\hline 3 & $\begin{array}{l}\text { Perendaman sel epitel dengan ekstrak } \\
\text { bunga telang selama } 15 \text { menit }\end{array}$ & $\begin{array}{l}\text { wama inti lebih gelap dan sitoplasma berwarna } \\
\text { ungu. }\end{array}$ \\
\hline 4 & Larutan cat diff quick & $\begin{array}{l}\text { wama inti lebih gelap dari sitoplasma yang } \\
\text { berwama biru. }\end{array}$ \\
\hline
\end{tabular}

Berdasarkan hasil penelitian bahwa pewarna alami ekstrak bunga telang (Clitoria ternatea L) yang diujikan pada hapusan sel mukosa mulut menghasilkan perbedaan dari setiap perlakuan pada setiap waktu perendaman. Bunga telang (Clitoria ternatea $L$ ) digunakan sebagai bahan alami pengganti methyelen blue pada pengecatan diff quik. warna biru yang dihasilkan oleh bunga telang karena adanya kandungan antosianin. Sedangkan komponen yang terdapat pada pewarnaan diff quik adalah methylne blue. Cat methyelen blue sendiri mempunyai fungsi sebagai pewarna inti sel.

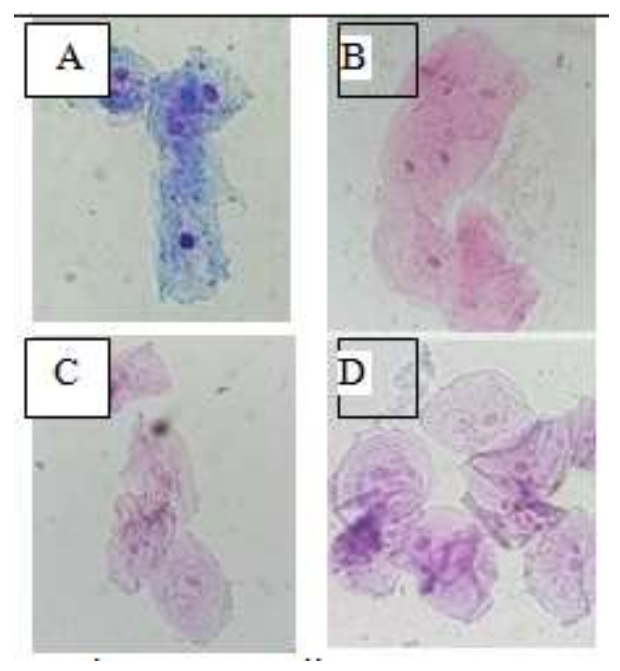

Gambar 1. Hasil pengamatan sel epitel menggunakan pengecatan Diff Quik (A) dan kombinasi Diff Quik - Bunga telang dengan perendaman 2 menit (B), 5 menit (C), dan 15 menit (D) dengan pembesaran 400×.

Perbandingan hasil pengamatan menggunakan mikroskop dari control (gambar A) dengan pewarnaan diff quik sel yang tampak terwarnai dengan baik. Penelitian ini menggunakan pewarna ekstrak bunga telang (Clitoria ternatea L) konsentrasi 1:5 dengan varian waktu perendaman 2 menit, 5 menit dan 15 menit. Pada hasil pengamatan (gambar 
B) dengan perlakuan perendaman selama 2 menit menghasilkan inti sel dan sitoplasma pada preparat tampak merah. Warna merah yang dihasilkan dari larutan eosin yang lebih kontras terlihat dari pada pewarnaan alami ekstrak bunga telang (Clitoria ternatea L). Hasil berbeda ditunjukan pada pengamatan (gambar C) yang direndam ekstrak bunga telang (Clitoria ternatea $L$ ) selama 5 menit yang menunjukan hasil inti sel yang sedikit lebih gelap dan sitoplasma yang tampak keunguan. Pada pengamatan (gambar D) yang direndam selama 15 menit ektrak bunga telang (Clitoria ternatea $L$ ) menghasilkan warna yang lebih baik dan lebih kontras dibandingkan perendaman sebelumnya. Inti sel yang lebih gelap dan warna sitoplasma yang berwarna ungu.

Pada bunga telang menghasilkan warna biru yang berasal dari adanya kandungan antosianin. Antosianin mempunyai sifat antioksidatif yang dapat menghasilkan warna merah sampai biru [10]. Ekstrak bunga telang (Clitoria ternatea L.) dijelaskan pada [5] dapat digunakan untuk alternatif pewarnaan untuk pewarna preparat sel darah hewan dan untuk mendapatkan ekstrak zat warna antosianin harus dilakukan ekstraksi [9].

Pada penelitian digunakan larutan alluminium chlorida anhydrat 1\% dan larutan Fe chlorid hexahirat 1,2\% sebagai larutan ekstraksi bunga telang yang berfungsi sebagai mordan. Pada media basa antosianin pada bunga telang akan menjadi warna ungu dan biru [1]. Menurut [5] penganti pewarna methyelen blue larutan ektrasi pewarna alami harus bersifat basa. Dengan menambahkan larutan alluminium chlorida anhydrat $1 \%$ dan larutan Fe chlorid hexahirat $1,2 \%$.

Larutan mordan bertujuan untuk mempertahankan warna yang terbentuk dari zat alami. Membantu pengamatan pada objek yang akan diamati untuk menghindari adanya proses pemudaran. Pewarna mordant merupakan ion logam polivalen yang membentuk kompleks koordinasi dengan pewarna tertentu yang kemudian melekat pada jaringan [16]. Penambahan larutan mordan gunakan sebelum proses pewarnaan. Mordan yang berasal dari senyawa logam yang umum digunakan untuk pewarnaan jaringan ialah seperti garam alluminium, potasium, $\mathrm{Cr}$, dan $\mathrm{Fe}$ [14] [12].

Pada hasil penelitian ini, ekstrak bunga telang mampu sebagai penganti methylen blue dengan penambahan larutan mordan akan tetapi kelemahan dari penggunaan pewarnaan alami ini adalah membutuhkan waktu perendaman yang lebih lama dari pengecatan diff quik.

\section{KESIMPULAN}

Berdasarkan hasil penelitian perbandingan pewarna alami dari ekstrak bunga telang (Clitoria ternatea $L$ ) sebagai pengganti methylene blue pada pengecatan diff quik bahwa pewarnaan dengan methylen blue pada sel epitel mukosa mulut tampak terwarnai lebih baik dibandingkan ekstrak bunga telang (Clitoria ternatea L) dengan perlakuan perendaman selama 15 menit yang menghasilkan warna lebih kontras dari pada perlakuan perendaman 2 menit dan 5 menit.

\section{REFERENSI}

[1] A. Abdullah and A. Apriandi, “Aktivitas antioksidan dan komponen bioaktif keong Ipong-ipong (Fasciolaria salmo),” J. Pengolah. Has. Perikan. Indones., vol. 14, no. 1, 2011.

[2] A. Suebkhampet and P. Sotthibandhu, "Effect of using aqueous crude extract from butterfly pea flowers (Clitoria ternatea L.) as a dye on animal blood smear staining," Suranae J. Sci. Technol., vol. 19, no. 1, pp. 15-19, 2012.

[3] B. J. Bain, Blood cells: a practical guide. John Wiley \& Sons, 2014.

[4] F. HECKNER, M. FREUND, and S. I. WANANDI, “Atlas Hematologi: Praktikum Hematologi dengan Mikroskop (Praktikum der mikroskopischen Hamatologie)," 1999.

[5] I. Fathoni, "PEMANFAATAN BENTONIT TEKNIS SEBAGAI ADSORBEN ZAT WARNA," UNESA $J$. Chem., vol. 5, no. 3, 2016.

[6] J. M. Bueno, P. Sáez-Plaza, F. Ramos-Escudero, A. M. Jiménez, R. Fett, and A. G. Asuero, “Analysis and antioxidant capacity of anthocyanin pigments. Part II: chemical structure, color, and intake of anthocyanins," Crit. Rev. Anal. Chem., vol. 42, no. 2, pp. 126-151, 2012.

[7] K. S. Budiasih, "Kajian potensi farmakologis bunga telang (Clitoria ternatea)," in Prosiding Seminar Nasional Kimia UNY, 2017, vol. 21, no. 4, pp. 183-188.

[8] L. Abramian and H. El-Rassy, "Adsorption kinetics and thermodynamics of azo-dye Orange II onto highly porous titania aerogel," Chem. Eng. J., vol. 150, no. 2-3, pp. 403-410, 2009. 
[9] M. A. Hartono, E. M. E. Purwijantiningsih, and S. Pranata, "Pemanfaatan ekstrak bunga telang (Clitoria ternatea L.) sebagai pewarna alami es lilin,” Fak. Teknobiologi Univ. Atma Jaya Yogyakarta, 2013.

[10] N. Ahmadiani, R. J. Robbins, T. M. Collins, and M. M. Giusti, “Anthocyanins contents, profiles, and color characteristics of red cabbage extracts from different cultivars and maturity stages," J. Agric. Food Chem., vol. 62, no. 30, pp. 7524-7531, 2014.

[11] O. Hamdaoui and M. Chiha, "Removal of Methylene Blue from Aqueous Solutions by Wheat Bran.," Acta Chim. Slov., vol. 54, no. 2, 2007.

[12] O. G. Avwioro et al., "Curcuma longa extract as a histological dye for collagen fibres and red blood cells," J. Anat., vol. 210, no. 5, pp. 600-603, 2007.

[13] O. R. Fennema and S. R. Tannenbaum, "Introduction to food chemistry," FOOD Sci. Technol. YORKMARCEL DEKKER-, pp. 1-16, 1996.

[14] S. A. Al-Tikritti and F. Walker, "Anthocyanin BB: a nuclear stain substitute for haematoxylin.," J. Clin. Pathol., vol. 31, no. 2, p. 194, 1978.

[15] S. Wahyuni and V. R. Tosiyana, "Identifikasi preparat gosok tulang femur ayam (Gallus gallus) dengan pewarnaan alami bunga telang (Clitoria ternatea L.)," in Prosiding Seminar Nasional Pendidikan Biologi, 2018.

[16] V. Vinukumar, K. V Kalaranjini, B. Krishnaswamy, and S. Vasudevan, "Utility of automation in assessment of haematological profile and typing of anaemia in pre-school children--a tertiary centre study," J. Evol. Med. Dent. Sci., vol. 3, no. 16, pp. 4310-4316, 2014. 